\title{
Extractable Lipids of Gram-Negative Marine Bacteria: Fatty-Acid Composition
}

\author{
JAMES D. OLIVER ${ }^{1}$ and RITA R. COLWELL ${ }^{2}$ \\ Department of Biology, Georgetown University, Washington, D.C. 20007
}

\begin{abstract}
Fatty-acid compositions were determined for 20 strains of marine and estuarine bacteria and two strains representative of terrestrial species. Results showed that the fatty acids of marine bacteria differed little from those of nonmarine organisms, and a primary role for hexadecenoic acid was indicated. Of the 20 strains examined, with the exception of one, the major fatty-acid species were C16, C16:1, and C18:1. Significant differences were observed among the fatty-acid patterns of the various bacterial genera included in the set of 20 strains examined, and rapid differentiation of most of the genera could thus be accomplished. A recently isolated marine species demonstrated a unique fatty-acid pattern wherein branched acids formed the major fatty-acid class. Effects of culture age, growth temperature, and salt concentration of the medium on the fatty-acid profiles were also investigated.
\end{abstract}

The biochemistry of marine bacteria has only recently been investigated in any detail. Most of the reports on marine bacteria have been concentrated on the distribution, taxonomy, and cytology of these microorganisms. Other than a few reports on the fatty acids and phospholipids of marine bacteria $(3,13,20,45$; R. Hardy, G. Hobbs, P. R. Mackie, and R. W. Horsley, Proc. Soc. Gen. Microbiol. 5 :iii), most of which involved only a cussory examination of these compounds, very little information is available on the lipids of marine bacteria. Recently, the phospholipids of a variety of marine and estuarine bacteria were reported by Oliver and Colwell (44); this represented an attempt to compare, for the first time, the lipids of marine organisms with those of terrestrial bacteria. The phospholipids phosphatidylethanolamine, phosphatidylglycerol, and lyso-phosphatidylethanolamine were found to be predominant in all of the organisms examined. The fatty acids of 20 marine and estuarine bacteria were examined in an extension of the phospholipid study.

(This work is abstracted from a dissertation by J.D.O. in partial fulfillment of the requirements for the Ph.D. degree at Georgetown Univ., Washington, D.C.)

\footnotetext{
'Present address: Department of Biochemistry, Vachon Hall, University of Ottawa, Ottawa, Canada, K1N 6N5.

${ }^{2}$ Present address: Department of Microbiology, University of Maryland, College Park, Md. 20742.
}

\section{MATERIALS AND METHODS}

Bacterial strains. Twenty-two bacterial strains were employed (Table 1), 16 of which were of marine origin. Strain labels with the prefix " $3 \mathrm{~S}$ " indicate that the strains were isolated from a sediment sample collected in the Atlantic Ocean. Classification of the sediment isolates was discussed previously (44).

Growth of cultures. All strains except two were grown in an artificial seawater medium (44). The two terrestrial strains, Vibrio cholerae ATCC 14033 and Pseudomonas aeruginosa ATCC 14216, were grown in a medium identical to that used for the marine isolates but with a $0.5 \% \mathrm{NaCl}$ solution, rather than artificial seawater, used as diluent. Cells were grown at $25 \mathrm{C}$ to the late logarithmic phase as described previously (44).

Fatty-acid methyl ester preparation. Methods for extraction of lipids from pellets of the harvested cells and freeing the extracts from nonlipid contaminants have been described (44). Fatty-acid methyl esters were prepared from the purified lipid extracts according to the method of Brockerhoff (10). To a sample of the lipid extract dissolved in chloroform was added $1.0 \mathrm{ml}$ of $0.5 \mathrm{~N}$ methanolic $\mathrm{KOH}$. After shaking, the mixture was allowed to remain at room temperature for $10 \mathrm{~min}$, after which $1.0 \mathrm{ml}$ of $1.0 \mathrm{~N} \mathrm{HCl}$ was added. The mixture was again shaken, and the methyl esters were extracted three times with $1.0-\mathrm{ml}$ samples of petroleum ether. The extracts were combined and evaporated under nitrogen, then taken up in carbon disulfide for analysis by gas-liquid chromatography. Fatty-acid methyl esters were kept in glass tubes fitted with Teflon-lined stoppers, under nitrogen, at $-10 \mathrm{C}$.

Fatty acids were hydrogenated in petroleum ether, with palladium chloride as a catalyst. Hydrogenated fatty acids were brominated according to the method of Brian and Gardner (9) to test for the presence of 
TABLE 1. Strains used in the study

\begin{tabular}{|c|c|c|}
\hline Strains $^{a}$ & Habitat $^{b}$ & Source \\
\hline $\begin{array}{l}\text { Vibrio algosus ATCC } 14390 \\
\text { V. marinofulvus ATCC } 14395 \\
\text { V. alginolyticus } 166-70 \\
\text { V. parahaemolyticus ATCC } 17802 \\
\text { V. marinus strain PS-207 } \\
\text { V. cholerae ATCC } 14033 \\
\text { Agrobacterium stellulatum ATCC } 15215 \\
\text { Achromobacter aquamarinus ATCC } 14400 \\
\text { Spirillum linum ATCC } 11336 \\
\text { Pseudomonas perfectomarinus ATCC } 14405 \\
\text { Pseudomonas aeruginosa ATCC } 14216 \\
\text { Photobacterium fischeri ATCC } 7744 \\
\text { Arthrobacter marinus ATCC } 25374 \\
\text { 1ORR } 10\end{array}$ & $\begin{array}{l}\mathrm{E} \\
\mathrm{E} \\
\mathrm{T} \\
\mathrm{M} \\
\mathrm{M} \\
\mathrm{M} \\
\mathrm{M} \\
\mathrm{T} \\
\mathrm{M} \\
\mathrm{M} \\
\mathrm{E}\end{array}$ & $\begin{array}{l}\text { Associated with marine kelp. ZoBell and } \\
\text { Upham (56). } \\
\text { Seawater. ZoBell and Upham (56). } \\
\text { Received from R. Sakazaki (National Insti- } \\
\text { titue of Health, Tokyo) as strain 166-70. } \\
\text { Skin of a Pacific cod. Colwell (16). } \\
\text { El Tor Station, 1930. Suggested neotype. } \\
\text { Knösel. } \\
\text { Seawater. ZoBell and Upham (56). } \\
\text { Seawater. Rittenberg. } \\
\text { Seawater and marine mud. ZoBell and Up- } \\
\text { ham (56). } \\
\text { Seawater. Received from G. Jones. } \\
\text { Water sample from Rhode River, Md. by T. } \\
\text { Kaneko. } \\
\text { Marine sediments. } \\
\text { Marine sediments. } \\
\text { Marine sediments. } \\
\text { Marine sediments. } \\
\text { Marine sediments. } \\
\text { Marine sediments. } \\
\text { Marine sediments. } \\
\text { Marine sediments. }\end{array}$ \\
\hline
\end{tabular}

${ }^{a}$ ATCC, American Type Culture Collection, Rockville, Md.

${ }^{\circ} \mathrm{M}$, Marine; E, estuarine; and T, terrestrial.

cyclopropane fatty acids. Silyl ether derivitization of the methyl esters was performed with Sil-Prep, obtained from Applied Science, Inc. (State College, Pa.), for detection of hydroxy fatty acids.

Gas-liquid chromatography. Fatty-acid methyl esters were examined by using a dual-column gas chromatography apparatus (model 7461, Packard Instrument Co.) equipped with dual flame ionization detectors. Three stainless steel columns $(1 / 8$ in by $6 \mathrm{ft}$; approximately 0.3 by $180 \mathrm{~cm}$ ), obtained from Applied Science, Inc., were routinely used for examination of the fatty-acid methyl esters. Ethylene-glycol adipate (10\% EGA) and diethyleneglycol succinate $(10 \%$ DEGS), both on 100- to 120-mesh Gas-Chrom Q, were used as polar columns, and $3 \%$ methyl silicone (SE-30), on 80- to 100-mesh Gas-Chrom Q, was used as a nonpolar column. The carrier gas used was ultra-high-purity nitrogen at a flow rate of $50 \mathrm{ml} / \mathrm{min}$. Column operating temperatures were $180 \mathrm{C}$ for the DEGS and SE-30 columns and $190 \mathrm{C}$ for the EGA. Injection port and detector temperatures were $15 \mathrm{C}$ above that of the column in use.

The following fatty-acid methyl ester standards were used for comparison: straight-chain saturated $\mathrm{C} 8$, $\mathrm{C} 10, \mathrm{C} 12, \mathrm{C} 14, \mathrm{C} 15, \mathrm{C} 16, \mathrm{C} 18, \mathrm{C} 20, \mathrm{C} 22$, and $\mathrm{C} 24$; straight-chain unsaturated $\mathrm{C} 14: 1, \mathrm{C} 16: 1, \mathrm{C} 18: 1$, $\mathrm{C} 18: 2, \mathrm{C} 18: 3$, and $\mathrm{C} 22: 1$; iso-branched $\mathrm{iC} 14, \mathrm{iC} 16$, $\mathrm{iC} 18$, and $\mathrm{iC} 20$; anteiso-branched $\mathrm{aC} 15, \mathrm{aC} 17, \mathrm{aC} 19$, and $\mathrm{aC} 21$; hydroxy-substituted $\mathrm{OH}-\mathrm{C} 14, \mathrm{OH}-\mathrm{C} 16$, and $\mathrm{OH}-\mathrm{C} 18$; and cyclopropane cycC 19.

Quantitation of the fatty acids was obtained by using a Hewlett-Packard model 3373B electronic integrator. Peak areas provided by the integrator were calculated from the total area, and from this was calculated the percentage each peak represented.

Identification of fatty acids. Identification of the fatty acids found in the lipid extracts was based on retention times on the three columns, relative to methyl myristate, by comparison of the relative retention values to equivalent chain-length graphs ( 1 , 2 ), by hydrogenation of the methyl esters to convert unsaturated species to the saturated analogs, by preparation of bromine derivatives of the hydrogenated acids to remove cyclopropane fatty acids, and by co-chromatography with the 28 fatty-acid methyl ester standards.

Effect of growth temperature on fatty-acid composition. A study of the effect of temperature on the fatty-acid profile of Vibrio marinus strain PS-207 was made. The organism was grown at 25 and $15 \mathrm{C}, \pm 0.5$ C. When the cells reached late logarithmic phase, they were harvested. The lipids were extracted and purified, and the fatty-acid methyl esters were prepared and examined by gas-liquid chromatography.

Effect of culture age on fatty-acid composition. The marine isolate $3 \mathrm{SE} 8$ was grown for 3.5-, 5-, 6.5-, 9-, and $96-\mathrm{h}$ time intervals, corresponding to points in the logarithmic, early stationary, and late stationary phases of growth, at $25 \mathrm{C}$. After cell harvest and lipid extraction, the fatty acids were prepared and examined.

The marine isolates $3 \mathrm{~S} 2$ and $3 \mathrm{SE} 7$ were similarly 
examined for effect of age on fatty-acid composition, each strain being grown for periods corresponding to logarithmic and middle stationary growth phases.

Effect of salt concentration on fatty-acid composition. To investigate the effects of salt concentration on the fatty-acid composition of the marine microorganisms, we prepared five $250-\mathrm{ml}$ side-arm flasks, each with $75 \mathrm{ml}$ of medium containing $0.1 \%$ proteose peptone (Difco) and $0.1 \%$ yeast extract (Difco), but with varying concentrations of " 3 -salts" solution, according to the following scheme. Flask one contained $0.4 \mathrm{M} \mathrm{Nacl}, 0.01 \mathrm{M} \mathrm{KCl}$, and $0.028 \mathrm{M}$ $\mathrm{MgSO}_{4} \cdot \mathrm{H}_{2} \mathrm{O}$, and was designated complete; flask two contained $0.2 \mathrm{M} \mathrm{NaCl}, 0.005 \mathrm{M} \mathrm{KCl}$, and $0.014 \mathrm{M}$ $\mathrm{MgSO}_{4} \cdot 7 \mathrm{H}_{2} \mathrm{O}$, and was designated one-half strength; flask three contained $0.1 \mathrm{M} \mathrm{NaCl}, 0.0025 \mathrm{M} \mathrm{KCl}$, and $0.007 \mathrm{M} \mathrm{MgSO}_{4} \cdot 7 \mathrm{H}_{2} \mathrm{O}$, and was designated onequarter strength; flask four contained $0.05 \mathrm{M} \mathrm{NaCl}$, $0.00125 \mathrm{M} \mathrm{KCl}$, and $0.0035 \mathrm{M} \mathrm{MgSO}_{4} \cdot 7 \mathrm{H}_{2} \mathrm{O}$, and was designated one-eighth strength; and flask five contained distilled water. All media were adjusted to $\mathrm{pH}$ 7.3 and were inoculated by picking a colony from a streak plate of the marine isolate 3 SE8 to the flask. The cultures were incubated at $27 \mathrm{C}$ on a reciprocal shaker. At periodic intervals, samples were removed to monitor growth by reading optical density at $660 \mathrm{~nm}$.

After harvesting the cells, we extracted and purified the pellets by following standard methods and prepared the fatty-acid methyl esters.

Chemicals. All extractions and derivitizations were performed by using glass-distilled chloroform, methanol, and petroleum ether obtained from Bodman Chemicals (Narberth, Pa.). Fatty-acid methyl ester standards were obtained from Supelco, Inc. (Bellefonte, $\mathrm{Pa}$.) and Applied Science Laboratories (State College, $\mathrm{Pa}$.). All other reagents and medium components were of the highest grade available.

\section{RESULTS}

In Table 2 are listed the results of the fatty-acid composition analyses of the 22 strains examined. Most striking was the predominance of the C16:1 component, the major fatty acid in extracts of 14 of the 22 strains. Of the remaining eight strains, C18:1 was the major fatty acid found in seven strains, with only the marine isolate 3 SE5 presenting a significantly different fatty-acid pattern. With the exception of strain 3SE5, all organisms revealed $\mathrm{C} 16, \mathrm{C} 16: 1$, and $\mathrm{C} 18: 1$ to be the major fatty acids. A composite of the fatty-acid profiles is provided in Fig. 1-3. As would be expected for fatty-acid profiles of true bacteria, the saturated acids were predominantly of even carbon number. Acids of short chain length occurred only in very small amounts, and no acids of greater than 20 carbons were present (43). All of the 22 strains examined possessed the straight-chain $\mathrm{C} 12, \mathrm{C} 13, \mathrm{C} 14, \mathrm{C} 15, \mathrm{C} 16$,
$\mathrm{C} 17, \mathrm{C} 18$, and the unsaturated $\mathrm{C} 16: 1$ and C18:1 fatty acids. C17:1 fatty acid was present in all but one strain.

Of the variety of fatty acids detected among the strains tested, only one is not usually found in bacterial lipids. The acid found to occur in 16 of the 22 strains in amounts ranging from traces to over $12 \%$ of the total had a carbon number of 19.0 on EGA columns, 19.3 on DEGS, and 18.9 on SE-30. Whereas such values would suggest an identity of normal $\mathrm{C} 19$, this component was found to be an unsaturated species. Hydrogenation of samples containing this acid caused a total loss of the peak with a proportional increase in the $\mathrm{C} 18$ component. The possibility of its being a hydroxy fatty acid was ruled out, as these are not lost on hydrogenation. The trimethylsilyl ether reagents failed to affect relative mobility of the fatty acid. Similarly, the possibility of its being a cyclic acid was negated, as only relatively vigorous hydrogenation, by using platinum oxide in the presence of glacial acetic acid, would result in the opening of the cyclopropane ring (14). Relative retention of this component did not correspond to the cyclic acids.

Based on retention time on several columns, conversion to $\mathrm{C} 18$ on hydrogenation, and identical mobility with $\mathrm{C} 18: 2$, the unknown component was identified as a straight-chain C18:2. Jamieson (29) reported an equivalent chain length on EGA of 18.98 for $18: 2 \omega 6$, which corresponds well with the observations of this study for the acid in question, although the positions of the double bonds were not determined.

From examination of Table 2 and Fig. 1-3, it can be seen that the $\mathrm{C} 16, \mathrm{C} 16: 1$, and $\mathrm{C} 18: 1$ acids formed the major portion of the total fatty-acid composition of the Vibrio strains, with $\mathrm{C} 16: 1$ predominating in all strains except the estuarine isolate, strain 10RR 10, in which a slightly higher amount of C18:1 occurred. Among the vibrios tested, $\mathrm{C} 16: 1$ ranged from 35 to $50 \%, \mathrm{C} 16$ from 11 to $31 \%$, and $\mathrm{C} 18: 1$ from 9 to $38 \%$, with averages of 41,20 , and $25.4 \%$, respectively. The quantitative variations in composition were reflected in the ratios of $\mathrm{C} 16: 1+\mathrm{C} 18: 1 / \mathrm{C} 16+\mathrm{C} 18$, which ranged from 1.7 to 6.4. Significant quantities of $\mathrm{C} 18: 2$ were found to occur in V. marinus strain PS-207, and lesser amounts occurred in $V$. algosus ATCC 14390 and $V$. marinofulvus ATCC 14395. With the exception of $\mathrm{C} 12$, only a very small proportion of the total fatty-acid composition existed as acids of less than C14 in any of the strains, although a number of saturated, unsat- 
urated, and branched short-chain acids were found to be present.

Pseudomonas perfectomarinus ATCC 14405 and $P$. aeruginosa ATCC 14216 were found to possess surprisingly similar fatty-acid composition. Extracts of both strains contained C18:1 as the major acid, with $\mathrm{C} 16: 1$ and $\mathrm{C} 16$ being the second and third most prominent. Only trace amounts of any fatty acid of less than 14 carbons were found, with $>95 \%$ of the fatty acid composition being the three major acids. The C18:1 acid did occur in greater amounts in the strain of $P$. aeruginosa, as $d$ id those acids of less than 16 carbons.

A significant difference in the fatty-acid profile of Arthrobacter marinus ATCC 25374, when compared with the other strains examined, was the presence of cyclopropane C17. Bromination confirmed the presence of cyclic C17, but cyclopropane C19 was not detected. Other than the occurrence of cyclic $\mathrm{C} 17$, the fatty acids of $A$. marinus ATCC 25374 were similar to those present in the Vibrio strains examined, as was the $\mathrm{C} 16: 1+\mathrm{C} 18: 1 / \mathrm{C} 16+$ C18 ratio.

The fatty-acid composition of Agrobacterium stellulatum ATCC 15215 showed a significantly high percentage of $\mathrm{C} 18: 1$. This fatty acid alone accounted for $>93 \%$ of the total fatty acids. Little $\mathrm{C} 16$ or C16:1 was detected, although these fatty acids were the two next most abundant species, accounting for 4.1 and $1.2 \%$, respectively, of the total fatty acids. Of the strains examined, only $A$. stellulatum ATCC 15215 did not contain detectable amounts of C17:1. Because of the high C18:1 content, the unsaturated-to-saturated $\mathrm{C} 16+\mathrm{C} 18$ ratio was extremely high (18.6), and the percentage of total unsaturated acids exceeded $94 \%$.

Achromobacter aquamarinus ATCC 15215 revealed a fatty-acid pattern with a predominance of $\mathrm{C} 18: 1(65 \%)$ and lower, but significant, amounts of $\mathrm{C} 16$ and $\mathrm{C} 16: 1$. The unsaturated-to-saturated $\mathrm{C} 16+\mathrm{C} 18$ ratio was, in addition, quite high, indicating the rather low concentration of $\mathrm{C} 16$.

The fatty-acid profile of Spirillum linum ATCC 11336 revealed a pattern similar to that obtained for the vibrios. The $\mathrm{C} 16$ and $\mathrm{C} 16: 1$ contents were in the same range, with the C18:1 percentage only slightly higher than that found among the vibrios. The unsaturated-tosaturated $\mathrm{C} 16+\mathrm{C} 18$ ratio was higher than that of the marine vibrios but was similar to ratios obtained for the estuarine vibrios.

With few exceptions, the fatty-acid composition of Photobacterium fischeri ATCC 7744 was found to be almost identical to that of the
Vibrio strains tested. The amounts of the three major acids, $\mathrm{C} 16: 1, \mathrm{C} 18: 1$, and $\mathrm{C} 16$, were in proportions similar to those of the vibrios, as were the unsaturated-to-saturated $\mathrm{C} 16+\mathrm{C} 18$ ratios. No acids of carbon number less than 12 were detected, with the exception of one acid which was not detected in any of the other strains examined and was believed to be a mono-unsaturated $\mathrm{C} 9$, occurring in significant quantity $(5.3 \%)$ in Photobacterium fischeri ATCC 7744. Identification of the fatty acid was based on relative retention time ( 0.19 relative to methyl myristate), indicating a carbon number of 9.2 , and loss on hydrogenation. The component was not observed to revert to a C9 acid on hydrogenation, however, and the carbon number of $C 9: 1$ should be 9.4 on EGA. Lower relative retention time could result from branched $\mathrm{C} 9: 1$, but hydrogenation would still cause a reversion of this component to a branched $\mathrm{C} 9$, not seen in this instance. Another possibility to be considered is that the component may not be a fatty acid but an aldehyde or fatty aldehyde $(4,23)$. Aldehydes have been shown to be a requirement for the luminescent system in bacteria, although the role played by these compounds is not fully understood (26). Such compounds have been shown by Gray (22) to have retention times slightly less than the corresponding fatty-acid methyl ester, as is the case for the dimethylacetal derivatives of aldehydes, formed by the procedures commonly used for the methylation of fatty acids. Unsaturated, as well as branched, aldehydes are also known, and the possibility that the unknown " $\mathrm{C} 9$ " component exists as one of these aldehydes must be considered.

Among the strains recently isolated from marine sediment, a diversity of quantitative patterns was observed, although qualitatively the. fatty-acid profiles were similar (see Fig. 1-3). Except for isolate 3SE5, the major fatty acids detected were $\mathrm{C} 16: 1$ (30-52\%), C16 (15-28\%), and C18:1 (14-31\%). All of the isolates, except $3 \mathrm{SE} 5$ and $3 \mathrm{~S} 2$, were identified as Vibrio spp. (44), and the ranges given were similar to those obtained for the reference Vibrio strains examined in this study, as were the average value $\mathrm{s}$ of the three acids $(\mathrm{C} 16: 1=39 \%, \quad \mathrm{C} 16=20.5 \%, \quad \mathrm{C} 18: 1=22 \%)$. The unsaturated-to-saturated $\mathrm{C} 16+\mathrm{C} 18$ ratios among the marine isolates (3SE5 excluded) were remarkably similar, ranging from 2.2 to 4 , as were the percentages of total unsaturated acids.

Although fatty-acid compositions of the majority of the sediment isolates were similar, a 
TABLE 2. Fatty-acid composition of lipids extracted from strains of species of the genus Vibrio and other genera of bacteria and from eight marine sediment isolates

\begin{tabular}{|c|c|c|c|c|c|c|c|}
\hline \multirow[b]{2}{*}{ Fatty acid } & \multicolumn{7}{|c|}{ Fatty-acid Composition (\% of total) } \\
\hline & $\begin{array}{c}\text { V. algosus } \\
\text { ATCC } \\
14390\end{array}$ & $\begin{array}{l}\text { V. marino- } \\
\text { fulvus } \\
\text { ATCC } \\
14395\end{array}$ & $\begin{array}{l}\text { V. marinus } \\
\text { PS-207 }\end{array}$ & $\begin{array}{l}\text { V. algino- } \\
\text { lyticus } \\
166-70\end{array}$ & $\begin{array}{c}V . \text { parahae- } \\
\text { molyticus } \\
\text { ATCC } \\
17802\end{array}$ & $\begin{array}{c}V . \text { cholerae } \\
\text { ATCC } \\
14033\end{array}$ & IORR1O \\
\hline \multirow{25}{*}{$\begin{array}{c}10 \\
\text { br11 } \\
11 \\
\text { br12 } \\
12 \\
\text { br13 } \\
13 \\
13: 1 \\
\text { i14 } \\
14 \\
14: 1 \\
\text { br15 } \\
15 \\
15: 1 \\
\text { i16 } \\
16 \\
16: 1 \\
\text { brit } \\
17 \\
17: 1 \\
\text { i18 } \\
18 \\
18: 1 \\
18: 2 \\
16: 1+18: 1 / \\
16+18 \\
\text { \% Unsaturated }\end{array}$} & \multirow[t]{2}{*}{$\operatorname{tr}^{a}$} & \multirow{3}{*}{$\begin{array}{l}0.1 \\
\operatorname{tr} \\
0.2\end{array}$} & 0.2 & \multirow[t]{2}{*}{$\operatorname{tr}$} & & \multirow[t]{3}{*}{$\operatorname{tr}$} & \multirow[t]{2}{*}{$\operatorname{tr}$} \\
\hline & & & $\operatorname{tr}$ & & & & \\
\hline & 0.1 & & 0.2 & $\operatorname{tr}$ & & & $\operatorname{tr}$ \\
\hline & \multirow{2}{*}{3.5} & \multirow{2}{*}{$\begin{array}{l}0.3 \\
\text { tr }\end{array}$} & $\begin{array}{l}\operatorname{tr} \\
5.4\end{array}$ & \multirow[t]{2}{*}{$\operatorname{tr}$} & 0.1 & \multirow[t]{2}{*}{0.1} & \multirow[t]{2}{*}{$\operatorname{tr}$} \\
\hline & & & & & $\operatorname{tr}$ & & \\
\hline & \multirow{3}{*}{ tr } & 0.2 & 0.5 & \multirow[t]{2}{*}{$\operatorname{tr}$} & tr & \multirow[t]{2}{*}{ tr } & \multirow[t]{2}{*}{$\operatorname{tr}$} \\
\hline & & & & & & & \\
\hline & & $\operatorname{tr}$ & & $\operatorname{tr}$ & $\operatorname{tr}$ & 0.1 & 0.4 \\
\hline & 2.6 & 1.9 & 3.7 & 1.3 & 1.5 & 4.2 & 1.2 \\
\hline & \multirow[t]{2}{*}{0.2} & 0.2 & 1.2 & 0.4 & 0.4 & 0.4 & 0.2 \\
\hline & & & & $\operatorname{tr}$ & $\operatorname{tr}$ & & 0.3 \\
\hline & 0.2 & 2.6 & 0.7 & 0.5 & 1.2 & 0.2 & 0.3 \\
\hline & tr & 1.0 & 0.2 & 0.3 & 0.5 & & 0.6 \\
\hline & & & & 0.7 & tr & 1.1 & 3.7 \\
\hline & 31.0 & 30.4 & 19.2 & 13.1 & 11.2 & 22.5 & 12.5 \\
\hline & 37.5 & 44.8 & 39.2 & 50.0 & 40.2 & 41.3 & 35.6 \\
\hline & & & & & & & 0.3 \\
\hline & $\operatorname{tr}$ & 1.6 & $\operatorname{tr}$ & 0.2 & 2.0 & $\operatorname{tr}$ & 0.3 \\
\hline & $\operatorname{tr}$ & 6.5 & $\operatorname{tr}$ & 1.7 & 3.8 & 1.1 & 3.2 \\
\hline & & & & & & & 0.2 \\
\hline & 3.1 & 1.1 & 1.6 & 0.5 & 1.0 & 1.1 & 3.0 \\
\hline & 19.8 & 9.0 & 15.4 & 31.2 & 38.0 & 27.9 & 36.7 \\
\hline & 1.9 & tr & 12.4 & & & & 2.1 \\
\hline & 17 & 17 & 26 & & & & \\
\hline & 59.2 & 61.6 & $\begin{array}{r}2.0 \\
68.4\end{array}$ & $\begin{array}{r}6.0 \\
83.6\end{array}$ & $\begin{array}{r}6.4 \\
82.9\end{array}$ & $\begin{array}{r}2.9 \\
70.7\end{array}$ & $\begin{array}{r}4.7 \\
78.4\end{array}$ \\
\hline & & & Fatty-acid & nposition (\% & of total) & & \\
\hline Fatty acid & $\begin{array}{c}\text { P. perfecto- } \\
\text { marinus } \\
\text { ATCC } 14405\end{array}$ & $\begin{array}{c}\text { P. aerugi- } \\
\text { nosa ATCC } \\
14216\end{array}$ & $\begin{array}{c}\text { A. stellu- } \\
\text { latum } \\
\text { ATCC } \\
15215\end{array}$ & $\begin{array}{c}\text { A. aqua- } \\
\text { marinus } \\
\text { ATCC } \\
14400\end{array}$ & $\begin{array}{c}\text { S. linum } \\
\text { ATCC } \\
11336\end{array}$ & $\begin{array}{c}\text { P. fischeri } \\
\text { ATCC } 7744\end{array}$ & $\begin{array}{c}\text { A. marinus } \\
\text { ATCC } \\
25374\end{array}$ \\
\hline $\begin{array}{r}10 \\
\text { br } 11\end{array}$ & tr & $\operatorname{tr}$ & $\operatorname{tr}$ & tr & $\operatorname{tr}$ & & tr \\
\hline 11 & tr & $\operatorname{tr}$ & $\operatorname{tr}$ & $\operatorname{tr}$ & $\operatorname{tr}$ & & $\begin{array}{l}\text { tr } \\
0.1\end{array}$ \\
\hline br 12 & & $\operatorname{tr}$ & & & & & $\mathrm{tr}$ \\
\hline 12 & 0.1 & $\operatorname{tr}$ & $\operatorname{tr}$ & $\operatorname{tr}$ & $\operatorname{tr}$ & 0.3 & 0.1 \\
\hline 12:1 & tr & & & & & & \\
\hline br 13 & & $\operatorname{tr}$ & $\operatorname{tr}$ & $\operatorname{tr}$ & & tr & \\
\hline 13 & tr & $\operatorname{tr}$ & tr & 0.1 & tr & 0.6 & 0.1 \\
\hline $13: 1$ & & $\operatorname{tr}$ & & & & & \\
\hline il 14 & 0.1 & & $\operatorname{tr}$ & $\operatorname{tr}$ & tr & $\operatorname{tr}$ & $\operatorname{tr}$ \\
\hline 14 & 1.1 & 1.0 & 0.1 & 0.2 & 0.8 & 7.9 & 0.1 \\
\hline $14: 1$ & 0.1 & $\operatorname{tr}$ & $\operatorname{tr}$ & 0.1 & & 0.7 & tr \\
\hline br 15 & & & & & $\operatorname{tr}$ & & \\
\hline 15 & 0.7 & $\operatorname{tr}$ & 0.1 & 0.1 & $\operatorname{tr}$ & 0.2 & 0.2 \\
\hline $15: 1$ & & & 0.1 & tr & & 0.1 & tr \\
\hline i16 & 0.1 & 0.1 & & & 0.1 & & \\
\hline 16 & 22.4 & 16.9 & 4.1 & 11.8 & 16.9 & 18.8 & 26.5 \\
\hline $16: 1$ & 24.2 & 34.4 & 1.2 & 21.4 & 40.5 & 39.4 & 41.7 \\
\hline
\end{tabular}


Table 2 (continued)

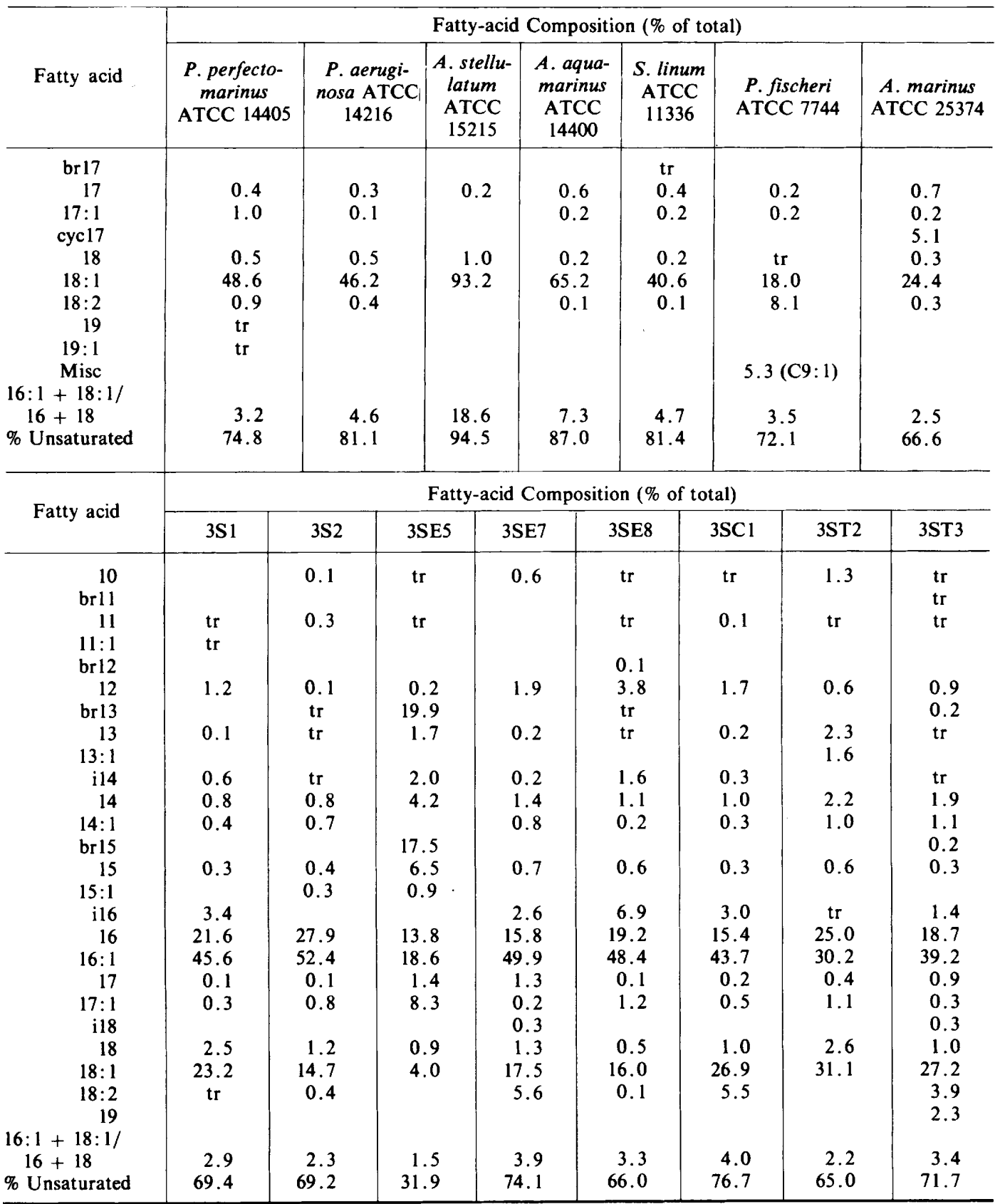

${ }^{a}$ Less than $0.1 \%$ of total.

few differences were detected and merit discussion. Isolate 3ST2 exhibited almost equal amounts of $\mathrm{C} 16$ and $\mathrm{C} 16: 1$, with the result that C18:1 was the major acid in the profile obtained for this strain, the only sediment isolate to demonstrate such a pattern. Isolate 3ST3 was the only sediment isolate to demonstrate the presence of $\mathrm{C} 19$ but was otherwise 

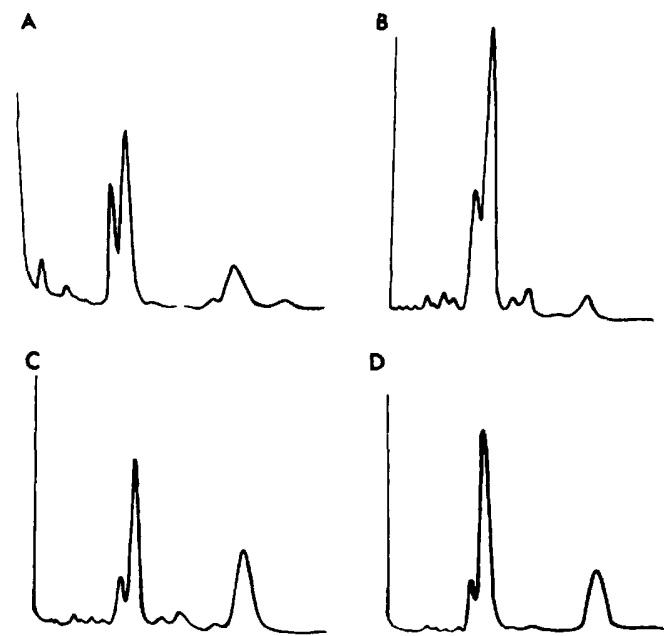

D

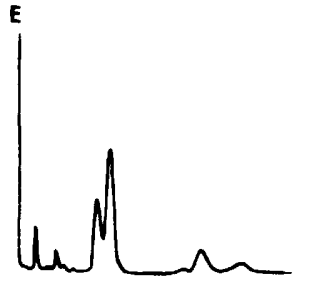

\section{$\mathbf{F}$}
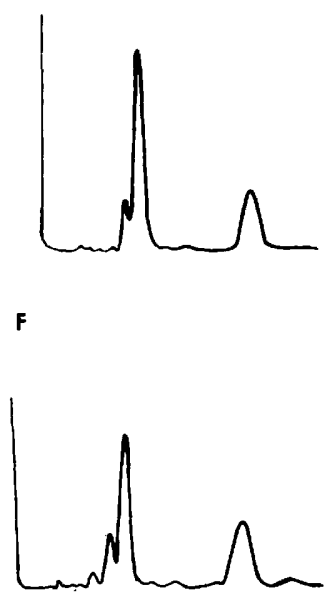

G

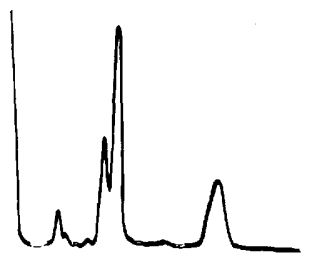

FIG. 1. Fatty-acid profiles. See text for procedural details. A, Vibrio algosus ATCC 14390; B, Vibrio marinofulvus ATCC 14395; $C$, Vibrio parahaemolyticus ATCC 17802; D, Vibrio alginolyticus 166-70; $E$, Vibrio marinus PS-207 (25 C); F, strain 10RR10; $G$, Vibrio cholerae ATCC 14033.

similar in fatty-acid profile to the other sediment isolates and the Vibrio strains. The presence of $\mathrm{C} 15: 1$ appeared to be characteristic of the vibrios examined, and isolates 3 SE5 and 3S2 also contained this acid. Unlike the other sediment isolates, the two organisms lacked the iso-branched $\mathrm{C} 16$ acid, occurring in small, but significant, quantities in all but one of the other sediment isolates. Isolate $3 \mathrm{~S} 2$ was, in general, similar to the other vibrio and marine sediment isolates examined.

The one exception to the general fatty-acid pattern observed among the sediment isolates was that obtained for isolate 3 SE5. Among the acids detected in extracts prepared from this organism were quantities of branched acids, the most abundant fatty-acid group (39.4\%). The main fatty-acid component was an iso-branched $\mathrm{C} 13$, constituting almost $20 \%$ of the fatty-acid total, with a branched $\mathrm{C} 15$ also occurring in significant quantity $(17.5 \%)$. The $\mathrm{C} 16$ and C16:1 acids amounted to only slightly greater than $32 \%$. Unsaturated acids, never less than $59 \%$ for the other 21 strains, totaled $31.9 \%$. Another unusual finding was the large $(8.3 \%)$
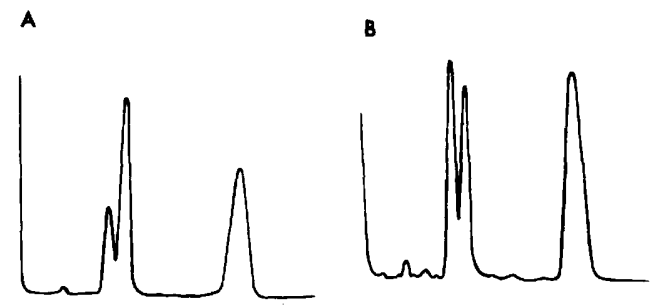

c

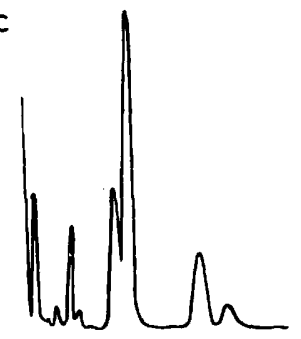

D

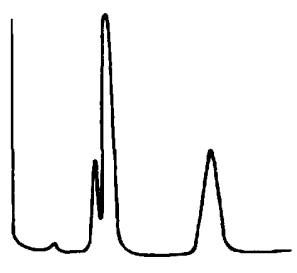

E
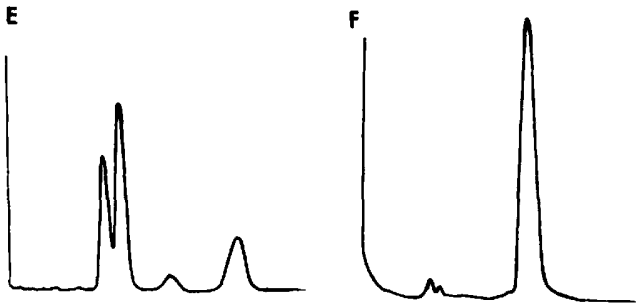

G

FIG. 2. Fatty-acid profiles. See text for procedural details. A, Pseudomonas perfectomarinus ATCC 14405; B, Pseudomonas aeruginosa ATCC 14216; $C$, Photobacterium fischeri ATCC 7744; $D$, Spirillum linum ATCC 11336; E, Achromobacter aquamarinus ATCC 14400; F, Agrobacterium stellulatum ATCC 15215; G, Arthrobacter marinus ATCC 25374. 


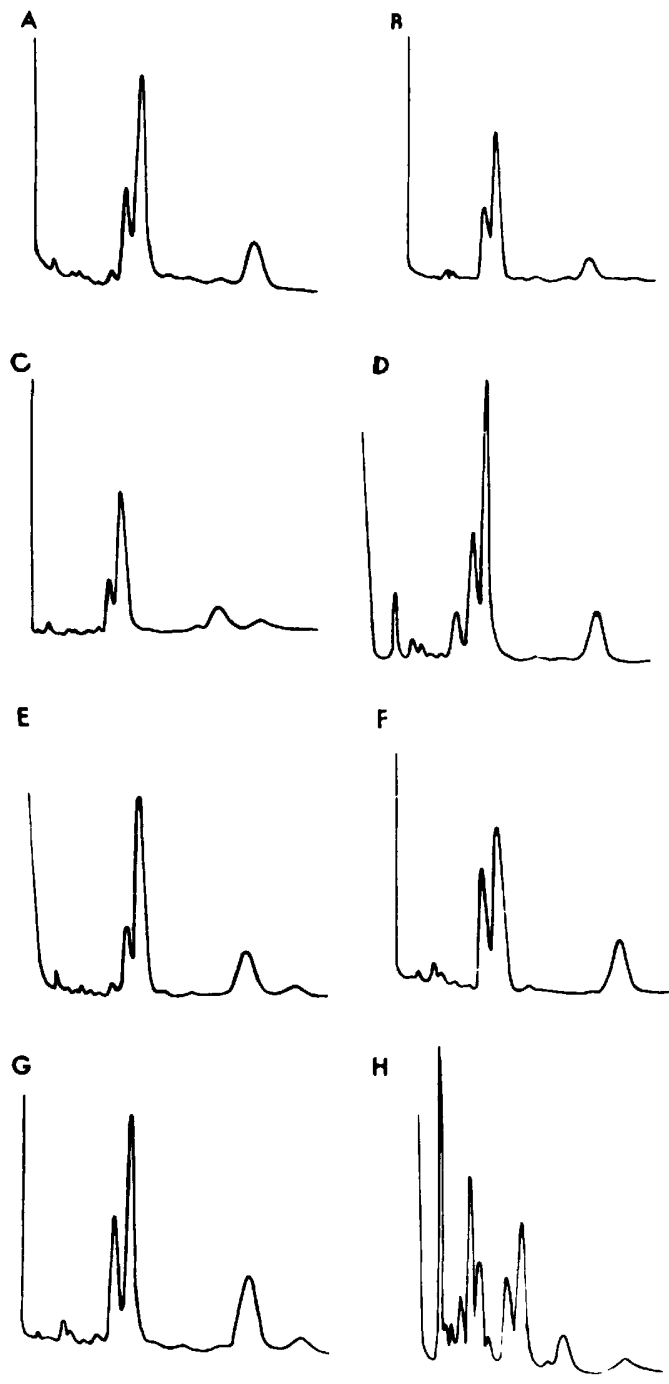

FIG. 3. Fatty-acid profiles. See text for procedural details. A, Strain $3 S 1 ; B$, strain $3 S 2(4 \mathrm{~h}) ; C$, strain $3 S E 7$ (4 h); $D$, strain $3 S E 8(5 h) ; E$, strain 3SC1; $F$, strain 3ST2; $G$, strain 3ST3; H, strain 3SE5.

quantity of C17:1 detected and low (4.0\%) content of C18:1.

Effect of culture age on fatty-acid composition. Extracts of marine sediment isolate $3 \mathrm{SE} 8$ were prepared from cells grown for $3.5,5,6.5$, 9 and $96 \mathrm{~h}$, and the effects of culture age on the fatty-acid composition of the marine bacterium were determined (see Fig. 4). Results obtained after quantitation of the fatty acids are listed in Table 3 . With few exceptions, changes in the fatty-acid composition were relatively minor. Of the major acids, only C16:1 was found to increase significantly, with

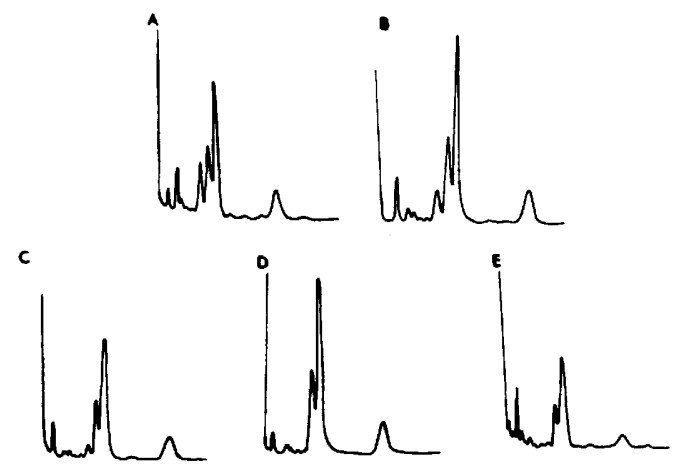

FIG. 4. Effect of culture age on the fatty-acid profile. See text for procedural details. The strain used was 3SE8. A, $3.5 h ; B, 5 h ; C, 6.5 h ; D, 9.5 h ; E, 96 h$.

TABLE 3. Effect of culture age on fatty-acid composition of strain $3 S E 8^{a}$

\begin{tabular}{c|r|r|r|r|r}
\hline \multirow{2}{*}{ Fatty acid } & \multicolumn{5}{|c}{ Growth of strain 3SE8 after } \\
\cline { 2 - 6 } & $3.5 \mathrm{~h}$ & $5 \mathrm{~h}$ & $6.5 \mathrm{~h}$ & $9 \mathrm{~h}$ & $96 \mathrm{~h}$ \\
\hline 10 & $\mathrm{tr}^{b}$ & 0.2 & $\mathrm{tr}$ & $\mathrm{tr}$ & $\mathrm{tr}$ \\
11 & 1.0 & $\mathrm{tr}$ & $\mathrm{tr}$ & $\mathrm{tr}$ & $\mathrm{tr}$ \\
$\mathrm{i} 12$ & 0.3 & 0.1 & $\mathrm{tr}$ & $\mathrm{tr}$ & - \\
12 & 2.1 & 4.2 & 4.5 & 1.8 & 4.4 \\
13 & 0.1 & 0.2 & 0.2 & $\mathrm{tr}$ & 0.5 \\
$\mathrm{i} 14$ & 6.7 & 0.9 & 0.9 & $\mathrm{tr}$ & 0.2 \\
14 & 0.9 & 1.4 & 1.0 & 1.3 & 1.8 \\
$14: 1$ & 0.3 & 0.3 & 0.2 & 0.1 & 0.3 \\
15 & 0.7 & 0.8 & 0.6 & 0.4 & 1.1 \\
$\mathrm{i} 16$ & 13.6 & 4.5 & 5.2 & 0.4 & 1.7 \\
16 & 16.3 & 19.4 & 20.9 & 22.2 & 18.8 \\
$16: 1$ & 35.4 & 46.8 & 43.6 & 50.6 & 44.8 \\
17 & 0.4 & 0.4 & 0.6 & 0.6 & 0.3 \\
$17: 1$ & 1.1 & 1.0 & 0.6 & 0.3 & 0.5 \\
18 & 1.8 & 0.6 & 0.6 & 0.9 & 0.9 \\
$18: 1$ & 18.5 & 17.2 & 20.6 & 21.1 & 22.0 \\
$18: 2$ & 0.7 & 2.0 & 0.5 & 1.4 & 2.7 \\
$18: 1 /$ & 3.0 & 3.2 & 3.0 & 3.1 & 3.4 \\
$16+18$ & & & & & \\
\% Unsaturated & 56.0 & 67.2 & 65.5 & 73.6 & 70.3 \\
\hline
\end{tabular}

${ }^{a}$ Cells were grown at $25 \mathrm{C}$ and harvested at indicated times. Results expressed as percent of total fatty-acid composition.

$b$ Less than $0.1 \%$ of total.

C16 increasing slightly; both leveled otf after 5 $\mathrm{h}$. In the case of $\mathrm{C} 18$, a small decrease was observed after the initial sampling, with a leveling off also at about $5 \mathrm{~h}$. The percentage of C18:1 increased slightly over the entire growth period, but the total change was small. Although iso-branched acids were detected only at low levels (except for isoC16 in the logarithmic phase), a slight increase in the 
parent acid paralleled the decrease of the iso-branched acid.

Fatty acids isolated from extracts prepared from marine sediment isolate 3SE7 after 4 and $15.5 \mathrm{~h}$ of growth are given in Table 4. Changes in the fatty-acid content over the growth periods studied, i.e., logarithmic and stationary phases of growth, were minor (see Fig. 5). Increases in both $\mathrm{C} 16: 1$ and $\mathrm{C} 16$ were observed in extracts from $3 \mathrm{SE7}$; these increases were approximately equivalent to those observed for 3SE8 over the same time periods. As noted for 3SE8, the $\mathrm{C} 18$ composition remained constant, although the C18:1 content of 3SE7 decreased

\begin{tabular}{|c|c|c|}
\hline \multirow[b]{2}{*}{ Fatty acid } & \multicolumn{2}{|c|}{ Growth of strain 3SE7 after } \\
\hline & $4 \mathrm{~h}$ & $15.5 \mathrm{~h}$ \\
\hline 10 & 0.6 & 0.7 \\
\hline 11 & & $\mathrm{tr}^{b}$ \\
\hline 12 & 1.9 & 2.0 \\
\hline 13 & 0.2 & 0.3 \\
\hline i14 & 0.2 & 0.5 \\
\hline 14 & 1.4 & 1.9 \\
\hline $14: 1$ & 0.8 & 0.5 \\
\hline 15 & 0.7 & 0.6 \\
\hline i16 & 2.6 & 3.8 \\
\hline 16 & 15.8 & 19.9 \\
\hline $16: 1$ & 49.9 & 53.8 \\
\hline 17 & 1.3 & 1.0 \\
\hline $17: 1$ & 0.5 & $\mathrm{tr}$ \\
\hline i18 & & 0.2 \\
\hline 18 & 1.3 & 1.2 \\
\hline $18: 1$ & 17.5 & 13.5 \\
\hline $18: 2$ & 5.6 & 0.3 \\
\hline $6: 1+18: 1 /$ & 3.9 & 3.2 \\
\hline $\begin{array}{l}6+18 \\
\text { Unsaturated }\end{array}$ & 74.1 & 68.2 \\
\hline
\end{tabular}

${ }^{a}$ Cells were grown at $25 \mathrm{C}$ and harvested at indicated times. Results expressed as percent of total fatty-acid composition.

${ }^{b}$ Less than $0.1 \%$ of total.
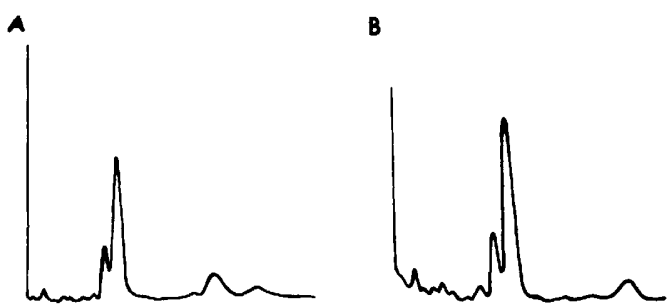

FIG. 5. Effect of culture age on the fatty-acid profile. The strain used was 3SE7. See text for procedural details. $A, 4 h ; B, 15 h$. with age. Unlike isolate $3 \mathrm{SE} 8$, all of the branched acids increased with age. Unsaturated C16 did not decrease as growth progressed toward the stationary phase. Also, unlike 3SE8, the percentage of total unsaturated fatty acid decreased.

A similar study of the fatty acids of isolate 3S2 is summarized in Table 5. As noted for isolates 3SE8 and 3SE7, the most interesting aspect of the study of the fatty acids of isolate 3S2 was the lack of change in any of the acids with age (see Fig. 6). Unlike isolates 3 SE7 and

TABLE 5. Effect of culture age on fatty-acid composition of strain $3 S 2^{a}$

\begin{tabular}{|c|c|c|}
\hline \multirow[b]{2}{*}{ Fatty acid } & \multicolumn{2}{|c|}{ Growth of strain $3 \mathrm{~S} 2$ after } \\
\hline & $4 \mathrm{~h}$ & $26 \mathrm{~h}$ \\
\hline 10 & 0.1 & 0.2 \\
\hline 11 & 0.3 & 0.3 \\
\hline 12 & 0.1 & 0.2 \\
\hline br13 & $\operatorname{tr}^{b}$ & tr \\
\hline 13 & $\operatorname{tr}$ & 0.4 \\
\hline i14 & tr & \\
\hline$\cdot 14$ & 0.8 & 0.6 \\
\hline $14: 1$ & 0.7 & 0.2 \\
\hline $\mathrm{i} 15$ & & 0.5 \\
\hline 15 & 0.4 & 1.5 \\
\hline $15: 1$ & 0.3 & 0.6 \\
\hline $\mathrm{i} 16$ & & 0.3 \\
\hline 16 & 27.9 & 24.2 \\
\hline $16: 1$ & 52.4 & 51.9 \\
\hline 17 & 0.1 & 1.3 \\
\hline $17: 1$ & 0.8 & 4.6 \\
\hline 18 & 1.2 & 1.0 \\
\hline $18: 1$ & 14.7 & 12.2 \\
\hline $18: 2$ & 0.4 & $\operatorname{tr}$ \\
\hline $16: 1+18: 1 /$ & 2.3 & 2.6 \\
\hline $16+18$ & & \\
\hline$\%$ Unsaturated & 69.2 & 69.5 \\
\hline
\end{tabular}

${ }^{a}$ Cells were grown at $25 \mathrm{C}$ and harvested at indicated times. Results expressed as percent of total fatty-acid composition.

${ }^{b}$ Less than $0.1 \%$ of total.
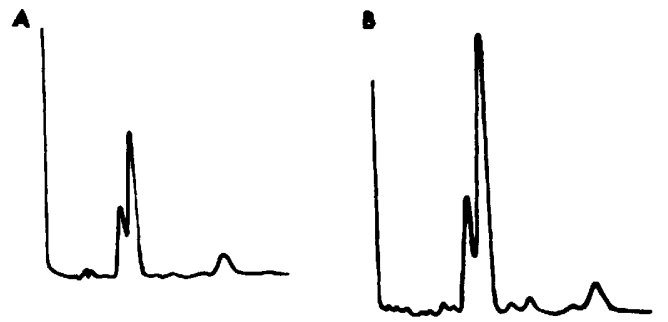

FIG. 6. Effect of culture age on the fatty-acid profile. Strain used was 3S2. See text for procedural details. $A, 4 h ; B, 26 h$. 
3SE8, however, slight decreases were found in $\mathrm{C} 16$ and $\mathrm{C} 18$ as well as in C16:1 and C18:1. The small changes observed were reflected by both the $\mathrm{C} 16+\mathrm{C} 18$ unsaturated-to-saturated ratio and the percentage of total unsaturated fatty acid, neither of which showed significant change.

Temperature effect on fatty-acid composition. The effect of fatty-acid composition of lowered growth temperature for Vibrio marinus strain PS-207, i.e., a drop in temperature from 25 to $15 \mathrm{C}$, is summarized in Table 6 (also see Fig. 7). The main difference observed was an appreciable increase in percentage of $\mathrm{C} 16: 1$. Of interest, however, was a decrease observed in C18:1 content, indicating selective unsaturatedacid increase. With the exception of $\mathrm{C} 17$, all saturated acids decreased with the lowered growth temperature, although a uniform increase in unsaturated species was not observed. Both the $\mathrm{C} 16: 1+\mathrm{C} 18: 1 / \mathrm{C} 16+\mathrm{C} 18$ ratio and the percentage of total unsaturated acid figures indicated a trend of increased unsaturated and decreased saturated fatty acids with lowered growth temperature.

Effect of salt concentration on fatty-acid

TABLE 6. Effect of temperature on the fatty-acid composition of V. marinus PS-207 ${ }^{a}$

\begin{tabular}{|c|c|c|}
\hline \multirow[b]{2}{*}{ Fatty acid } & \multicolumn{2}{|c|}{$\begin{array}{l}\text { Total fatty acid } \\
\text { growth }(\%) \text { at }\end{array}$} \\
\hline & $25 \mathrm{C}$ & $15 \mathrm{C}$ \\
\hline 10 & 0.2 & $\operatorname{tr}^{b}$ \\
\hline br1 1 & $\operatorname{tr}$ & $\operatorname{tr}$ \\
\hline 11 & 0.2 & $\operatorname{tr}$ \\
\hline br 12 & $\operatorname{tr}$ & \\
\hline 12 & 5.4 & 4.1 \\
\hline br13 & & tr \\
\hline 13 & 0.5 & $\operatorname{tr}$ \\
\hline 14 & 3.7 & 3.4 \\
\hline $14: 1$ & 1.2 & 1.8 \\
\hline 15 & 0.7 & 0.2 \\
\hline $15: 1$ & 0.2 & $\operatorname{tr}$ \\
\hline 16 & 19.2 & 16.9 \\
\hline $16: 1$ & 39.2 & 57.5 \\
\hline 17 & $\operatorname{tr}$ & 3.0 \\
\hline $17: 1$ & $\operatorname{tr}$ & 0.3 \\
\hline 18 & 1.6 & 0.3 \\
\hline $18: 1$ & 15.4 & 9.3 \\
\hline $18: 2$ & 12.4 & 3.1 \\
\hline $16: 1+18: 1 /$ & 2.6 & 3.9 \\
\hline $\begin{array}{l}16+18 \\
\% \text { Unsaturated }\end{array}$ & 68.4 & 72.0 \\
\hline
\end{tabular}

${ }^{a}$ Cells were grown to late logarithmic phase at indicated growth temperature. Results are expressed as percent of total fatty-acid composition.

$b$ Less than $0.1 \%$ of total. composition. The effect of lowered salt concentration on the growth of sediment isolate 3SE8 is illustrated in Fig. 8. Growth in the complete salts medium showed a rapid increase, with gradual slowing of the division rate after approximately $3 \mathrm{~h}$. Growth in the one-halfstrength medium also showed a rapid increase, but optical density readings were always lower than for cells grown in the complete salts medium. Cells grown in both salt concentrations were harvested after $7 \mathrm{~h}$, with yields of 2.3 and $1.0 \mathrm{~g}$ of cells (wet weight), calculated on a 1-liter basis for complete and one-halfstrength salts media. Cells grown in one-quarteror one-eighth-strength salts media showed considerable reduction in growth rates. Cells grown in 1.4-strength salts medium were harvested after $22.5 \mathrm{~h}$ (optical density, 0.29), yielding 0.4 $\mathrm{g}$ of cells (wet weight) per liter. Cells in oneeighth-strength salts medium were not examined further. Cells inoculated into a distilled water-based medium showed no growth after
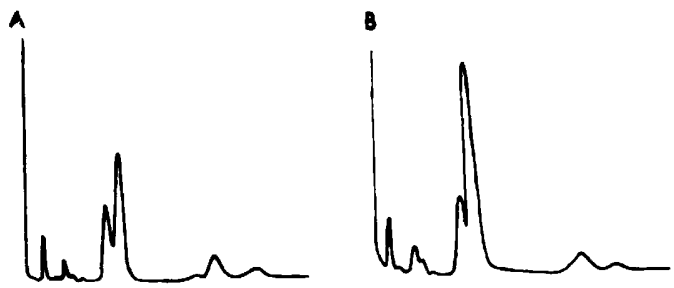

FIG. 7. Effect of growth temperature on the fatty-acid profile. Strain used was Vibrio marinus PS-207. See text for procedural details. A, 25 C; B, 15 C.

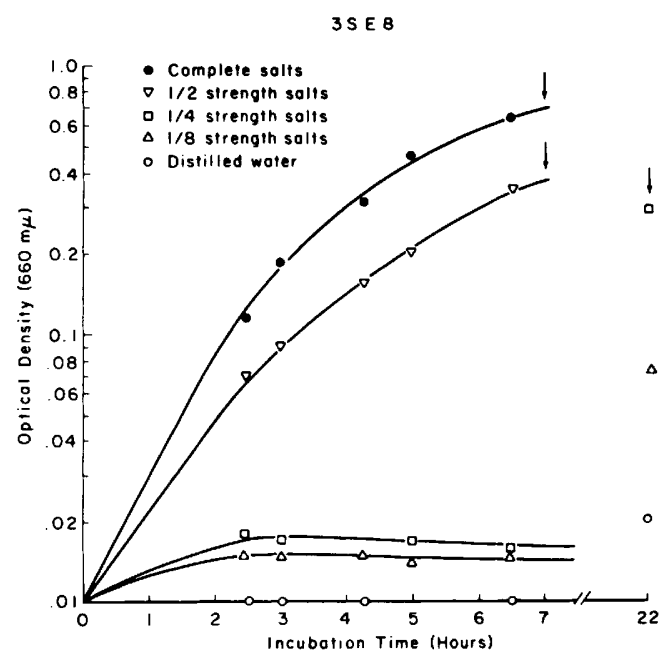

FIG. 8. Effect of reduced salt concentration on the growth of marine sediment isolate $3 S E 8$. 
$22.5 \mathrm{~h}$, as was expected, since the strain demonstrated a salt requirement for growth. The very slight increase in optical density that was noted was attributed to the limited increase in cell number supported by trace amounts of salts present in peptone and yeast extract (40, 54).

Light microscope examination of cells from one-half-strength salts medium showed no gross morphological differences compared with cells grown in complete medium. Cells from onequarter-strength salts medium were irregular, with distended and pear-shaped cells observed. The pleomorphism was attributed to a weakening of the cell envelope caused by interruptions of the mucopeptide layer, as shown by MacLeod (40) for a marine pseudomonad in a medium with salt content lowered beyond the critical point.

Examination of fatty-acids obtained from lipids of cells grown in the complete, one-halfand one-quarter-strength salts media (Table 7) showed a marked difference in the unsaturatedto-saturated $\mathrm{C} 16+\mathrm{C} 18$ ratios and in the percentage of total unsaturated fatty acids (see Fig. 9). Cells grown in the complete salts medium showed a $2: 1$ ratio of $\mathrm{C} 16: 1$ to $\mathrm{C} 16$,

TABLE 7. Effect of salt concentration on fatty acids of $3 S E 8^{a}$

\begin{tabular}{c|r|r|r}
\hline \multirow{2}{*}{ Fatty acid } & \multicolumn{3}{|c}{ Total fatty acids (\%) } \\
\cline { 2 - 4 } & $\begin{array}{c}\text { Complete } \\
\text { medium }\end{array}$ & $\begin{array}{c}\text { One-half- } \\
\text { strength } \\
\text { medium }\end{array}$ & $\begin{array}{c}\text { One-quarter- } \\
\text { strength } \\
\text { medium }\end{array}$ \\
\hline 10 & $\operatorname{tr}^{b}$ & 0.1 & tr \\
11 & tr & tr & 0.3 \\
12 & 4.0 & 0.7 & 4.0 \\
114 & 0.3 & tr & 0.2 \\
14 & 3.0 & 5.2 & 6.1 \\
$14: 1$ & 0.4 & 1.0 & 1.3 \\
15 & 1.7 & 1.7 & 1.2 \\
i16 & 1.2 & 0.1 & 1.6 \\
16 & 24.8 & 33.9 & 33.1 \\
$16: 1$ & 50.7 & 46.3 & 40.5 \\
17 & 0.8 & tr & 0.7 \\
$17: 1$ & 1.4 & tr & 0.2 \\
18 & 1.9 & 1.7 & 1.7 \\
$18: 1$ & 9.7 & 10.2 & 8.3 \\
$18: 2$ & tr & tr & 1.6 \\
$16: 1+18: 1 /$ & 2.3 & 1.6 & 1.4 \\
$16+18$ & & & \\
$\%$ Unsaturated & 62.3 & 57.5 & 51.9 \\
\hline
\end{tabular}

${ }^{a}$ Cells were grown at $27 \mathrm{C}$ in media containing various concentrations of salts (see Materials and Methods for details of media compositions). Results are expressed as percent total fatty-acid composition.

$b$ Less than $0.1 \%$ of total.
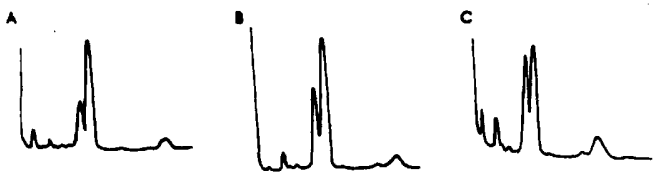

FIG. 9. Effect of reduced salt concentration on the fatty-acid profile of marine sediment isolate $3 S E 8$.

whereas cells grown in a one-quarter-strength salts medium showed a ratio of almost $1: 1$ for the two acids. The most marked change in the fatty acids of cells grown in the three media was in C16:1 composition; i.e., a steady decrease in content was observed. At the same time, an almost equal increase in the saturated C16 acid was evident, although little difference was observed between growth in the one-halfand one-quarter-strength salts media. No change in either $\mathrm{C} 18$ or $\mathrm{C} 18: 1$ was observed in cell extracts prepared from cells grown in any of the three media. The only other change of significance was in $\mathrm{C} 14$ and $\mathrm{C} 14: 1$ content, both of which increased as the salt content was lowered.

\section{DISCUSSION}

The finding that C16:1 was the most prominent fatty acid of extracts prepared from 14 of the 22 strains studied is contrary to most reports on fatty acids of gram-negative bacteria. $\mathrm{C} 16$ is commonly the major species $(13,38$, 43). The most likely explanation for this observation is in the growth temperature used here $(25 \mathrm{C})$ as opposed to that $(37 \mathrm{C})$ used in most of the studies reported in the literature. It is well established that lowering the growth temperature results in an increase in the percentage of unsaturated fatty acids $(31,43$, 50). C16:1 can be the predominant fatty acid, as was shown by Blumer et al. (7) for marine and terrestrial ammonia-oxidizing bacteria, by Kates and Hagen (32) for a psychrophilic Serratia strain, and for Photobacterium by Cho and Salton (13). This characteristic may be an effect of growth temperature and not solely a feature common to marine bacteria in general since the $\mathrm{C} 16: 1$ component was also prominent in the strain of Vibrio cholerae, a nonmarine species.

The presence of $\mathrm{C} 18: 2$ in the cell extracts contradicts the generally accepted observation that polyunsaturated fatty acids do not occur among members of the order Eubacteriales (38, $43,49)$. In pursuing this observation further, peptone and yeast-extract components of the medium used throughout the study were 
extracted and were found to contain the fatty acid C18:2. Thus, the strains examined in this study were able to incorporate C18:2 directly into phospholipids, or the acid may have been adsorbed to the cell surface. It is unlikely that adsorption occurred since the cells were washed three times with a salt solution composed of $\mathrm{NaCl}, \mathrm{KCl}$, and $\mathrm{MgSO}_{4}$ to remove any contaminating medium from the cell surface. In addition, such a washing procedure is almost universally carried out before extraction of bacterial lipids. If the C18:2 component was adsorbed from the medium, its occurrence would have been reported in earlier studies of fatty acids of bacteria. Although it has generally been accepted that bacteria lack polyunsaturated fatty acids, several reports of polyunsaturated fatty acids in bacteria have been published. Huston and Albro (28) reported the occurrence of a C20:4 acid in extracts of Sarcina lutea amounting to $4 \%$ of the total fatty-acid composition. Hunter and James (27) reported a C18:2 among fatty acids of Bacillus megaterium, about $5 \%$ of the total acids. Tornabene et al. (51) reported C18:2 among the fatty acids of Sarcina lutea grown in Trypticase soy broth, but not when the cells were grown in nutrient broth. The presence of C18:2 in $S$. lutea was confirmed in another study using combined gas chromatography-mass spectroscopy (52). Cho and Salton (13) reported the occurrence of C18:2 among the fatty acids of Aerobacter aerogenes, in two strains of Serratia marcescens, and in an unidentified Pseudomonas sp. Yano et al. (55) studied the fatty acids of Arthrobacter simplex grown in a variety of hydrocarbon-based media and reported the presence of $\mathrm{C} 18: 2$, to about $20 \%$ of the total fatty-acid composition, and confirmed their results by using mass spectroscopy. Romero and Brenner (47), in examining fatty acids of Pseudomonas aeruginosa grown with hexadecane as a sole carbon source, identified C18:1 and C18:2 as the major fatty acids, with the dienoic acid comprising over $35 \%$ of one of the lipid fractions. They also identified C18:2, $\mathrm{C} 20: 2$, and $\mathrm{C} 21: 2$ as excretory products in the growth medium.

That bacteria are capable of de novo synthesis of polyunsaturated fatty acids is evidenced by the work of Yano et al. (55) and Romero and Brenner (47), who showed conversion of hydrocarbons, used as sole carbon sources, to polyunsaturated fatty acids. The work of Cho and Salton (13) further suggests that simple adsorption of $\mathrm{C} 18: 2$ from the medium does not explain its presence in the fatty acid extracts, since isolated cell envelopes were used.
Unfortunately, except for the brief discussions by Yano et al. (55) and Romero and Brenner (47) on the possible mode of synthesis of the C18:2 component, none of the published reports provides an explanation of the significance of C18:2. Furthermore, the presence of C18:2 among the fatty acids of various bacterial species is not even acknowledged by many workers. The presence of polyenoic acids, confirmed by mass spectroscopy or found in isolated bacterial envelopes, should be a matter of considerable significance. Because C18:2 was identified in the extracts of Pseudomonas aeruginosa ATCC 14216 (Table 2) as well as in other nonmarine bacteria, it would appear that this acid is not restricted to marine bacteria. It may be significant, however, that it was found to occur in only one of the non-marine strains examined yet was present in 15 of the 20 estuarine and marine isolates examined. Further studies on the incorporation or synthesis, or both, of C18:2 clearly are needed.

It is interesting to note that in the Vibrio strains examined, unsaturated-to-saturated $\mathrm{C} 16+\mathrm{C} 18$ ratios were lowest (i.e., saturated acids were highest) in the marine strains. This is similar to the findings of Blumer et al. (7), who found higher degrees of saturatedness in the fatty acids of marine ammonia-oxidizers than in their non-marine counterparts. This was somewhat surprising, because lower temperatures associated with the marine environment suggest that a higher degree of unsaturated rather than saturated fatty acids should exist among the marine bacteria. A possible explanation may be that a growth temperature of $25 \mathrm{C}$ was used in this study. Since over $80 \%$ of the ocean is $5 \mathrm{C}$ or less (39), it can be assumed that a laboratory growth temperature of $25 \mathrm{C}$ is relatively high and would induce marine bacteria to synthesize greater amounts of saturated acids. On the other hand, estuarine isolates, the temperature of the normal habitats of which may reach $40 \mathrm{C}$ or more, and Vibrio cholerae, the optimal growth temperature of which is 37 $C$, would compensate for the low growth temperature of $25 \mathrm{C}$ by production of a greater proportion of unsaturated acids. Kojima (34) showed that when the growth temperature was set at $37 \mathrm{C}$, an unsaturated-to-saturated $\mathrm{C} 16+\mathrm{C} 18$ ratio of 1.4 was found for Vibrio parahaemolyticus and 1.1 to 1.9 for $V$. cholerae. A ratio of 1.35 was found for $V$. cholerae grown at $37 \mathrm{C}$ by Brian and Gardner (8). It is well established $(39,46)$ that a lowered growth temperature causes increased synthesis of unsaturated acids. However, our data suggest that the optimal growth tempera- 
ture of an organism should be considered when comparing fatty-acid profiles.

The fatty acids reported here for a number of Vibrio strains are in agreement with other published data $(8,13,34)$. The increased amount of $\mathrm{C} 16: 1$ observed to be present in the strains examined in this study can be attributed to the lower growth temperature of incubation.

The fatty-acid composition of the two Pseudomonas strains studied was found to be similar to that reported by Brian and Scholes (Bacteriol. Proc., p. 143, 1967) for P. aerugin$o s a$, although, again, the unsaturated content was higher in this study, most probably because of the differences in growth temperature used (25 versus $37 \mathrm{C}$ ). Hancock and Meadow (23) reported the occurrence of cyclic C19 in $P$. aeruginosa, about $38 \%$ of the total composition, when the cells were harvested from the stationary phase. The formation of the cyclic acid was due to a conversion of C18:1, a phenomenon observed by other workers as well $(18,43)$. No cyclic acids were found in extracts prepared from either $P$. aeruginosa ATCC 14216 or $P$. perfectomarinus ATCC 14405, but strain differences or the short incubation period used may be involved. The C18:1 content (47\%) reported by Hancock and Meadow (23) for $P$. aeruginosa harvested from the logarithmic phase was, however, almost identical to that found for the two pseudomonads examined in this study.

The most distinguishing feature of Arthrobacter marinus ATCC 25374 was the presence of cyclic $\mathrm{C} 17$. Cyclic acids have been reported in a variety of bacterial genera, including Escherichia, Agrobacterium, Serratia, Pseudomonas, Pasteurella, Salmonella, Aerobacter, Vibrio, and Lactobacillus $(5,8,12,23,25,30$, $31,36)$. Trace amounts of cyclic C19 may have been present in the extracts of $A$. marinus ATCC 25374, but this acid was not detected; both fatty acids might have been found in greater concentrations if a longer incubation time $(19,23,31,43)$ or a higher growth temperature had been used $(31,33)$. The few reports available on the fatty acids of Arthrobacter spp. have indicated a composition similar to that of the gram-positive bacteria, with branched acids as the predominant form. Shaw and Stead (48) examined the fatty acids of three terrestrial species of Arthrobacter and reported two anteiso-branched acids to comprise over $94 \%$ of the total composition. Kostiw et al. (35), reporting on the membrane lipids of growing and starving cells of $A$. crystallopoietes, noted a similar fatty-acid pattern in the cells of both growth stages, with the anteiso acids $\mathrm{C} 15$ and $\mathrm{C} 17$ comprising $88 \%$ of the total acids. Similar results have been reported by Yano et al. (55) for $A$. simplex. It is evident that the fatty acids of $A$. marinus ATCC 25374 , the type strain of the species, are in no way similar to those of strains of other species of this genus and are, in fact, quite typical of gram-negative bacteria in general. On the basis of the phospholipid composition, the taxonomic data $(6,44)$, and the fatty-acid profiles reported here, it is concluded that $A$. marinus should be removed from the genus Arthrobacter. Baumann et al. (6) have suggested placement of this organism in the genus Pseudomonas.

The percentage of C18:1 in Agrobacterium stellulatum ATCC 15215 ( $>93 \%$ of total acids) served to differentiate this strain readily from the other strains examined. There was a lack of cyclic fatty acids in extracts of this marine isolate, yet these have been reported for $A$. tumefaciens $(25,26,30)$ and $A$. radiobacter (21). Marr and Ingraham (41) noted, however, that in $E$. coli the formation of cyclic $\mathrm{C} 17$ was very minor at low growth temperatures, being formed in substantial amounts only at a temperature of $43 \mathrm{C}$. Effect of age was also demonstrated, and a 12-fold increase in the cyclic $\mathrm{C} 17$ concentration was shown to occur during the stationary phase compared with cells harvested during the logarithmic phase. Similarly, cyclic C19 could only be detected in cells harvested at the stationary phase. If the same effects are operating for members of the genus Agrobacterium, then it must be assumed that the parent unsaturated acids (C16:1 and C18:1) would still be represented in significant quantities until the cyclic acids are formed. Our finding that $93 \%$ of the total acids were represented by $\mathrm{C} 18: 1$ suggested that this was a plausible assumption. If the amounts of $\mathrm{C} 18: 1$ and cyclic C19 acids found by both Hildebrand and Law (25) and Kaneshiro and Marr (30) are summed, totals of 84 and $77 \%$, respectively, are obtained from the two studies. These amounts are in the range reported here for C18:1. The total of $91 \%$ unsaturated fatty acids (including cyclic acids) reported by Hildebrand and Law is very close to the results of this study, using $A$. stellulatum ATCC 15215. Other than the C18:1 and cyclic C19 fatty acids reported for $A$. tumefaciens (25), the amounts of the acids remaining were quite similar to those found here for A. stellulatum ATCC 15215.

The only report concerning the fatty acids of Achromobacter spp. is a note by Hardy et al. (Proc. Soc. Gen. Microbiol. 5:iii), who stated only that the major fatty acids found were C18:1 and C16:1 in two closely related species isolated from Atlantic salmon. Whereas the 
overall fatty-acid composition appeared to be, in general, similar to that of the other organisms examined, low concentrations of $\mathrm{C} 16$ and $C 16: 1$ and a moderately high concentration of $\mathrm{C} 18: 1$ served to differentiate this genus from the other genera studied.

The similarity in fatty-acid profiles of Spirillum linum ATCC 11336 and of the vibrios might be expected, since both are members of the same family (Spirillaceae). This is the first report on the fatty-acid composition of a Spirillum strain, and it is, therefore, impossible to compare this result with data for strains of other species of this genus. Based on the close similarity of $S$. linum to the vibrios examined, however, it appears that the relatively close taxonomic relationship of these two genera is justified on the basis of fatty-acid composition.

Other than the finding of higher amounts of $\mathrm{C} 14$, trace amounts of $\mathrm{C} 18$, and a rather high concentration of $\mathrm{C} 18: 2$, the fatty-acid composition of Photobacterium fischeri ATCC 7744 was observed to be similar to that of the vibrios examined. Such a similarity in fatty-acid composition might be expected, as the phospholipid pattern was found to be similar (44), and a close taxonomic relationship between $P$. fischeri and Vibrio spp. has been observed (16, 17). The deoxyribonucleic acid base composition data obtained for strains of Photobacterium spp. $(15,17)$ indicate that the genus is an artificial construct based on the single characteristic of luminescence. It is proposed that Photobacterium fischeri be placed in the genus Vibrio, as suggested by Lehmann and Neumann in 1896 (37). The fatty-acid composition determined for $P$. fischeri ATCC 7744 was similar to that reported for $P$. albensis by Cho and Salton (13), the only other report available on members of this genus. No component corresponding to that tentatively identified as an unsaturated $\mathrm{C} 9$ in $P$. fischeri ATCC 7744 was identified in the luminescent estuarine isolate 1ORR 10.

As with phospholipids of the eight sediment isolates (44), the fatty acids of these bacteria revealed a wide range in the quantitative fatty-acid patterns, although qualitatively the isolates were similar. The patterns observed were, for the most part, similar to those of the reference Vibrio strains examined. Such close similarities might be expected, since from the deoxyribonucleic acid base composition analyses and the morphological and biochemical data, all but two of the isolates (strains $3 \mathrm{~S} 2$ and 3SE5) were identified as belonging to species of the genus Vibrio (44).

Isolate 3SE5 was similar, with respect to fatty-acid composition, to the gram-positive bacteria which are known to contain considerable amounts of branched, but little unsaturated, fatty acids $(13,38,43)$. Despite these similarities, 3SE5 is a gram-negative bacterium. Other comparable situations have been reported (e.g., the fatty acids of the extreme thermophile Thermus aquaticus and of Escherichia alcalescens). Ray et al. (46) reported the major fatty acid of $T$. aquaticus to be an iso-branched C15 (35-56\%), with the second most abundant species being an iso-branched C15 (28-33\%). Cho and Salton (13) reported a branched $\mathrm{C} 17$ acid to be the second most abundant component $(26.4 \%)$ in the fatty acids of $E$. alcalescens, with $\mathrm{C} 16$ predominant $(46 \%)$. The lipids of isolate 3SE5 appeared to be similar to those typical of gram-negative bacteria, i.e., they lacked the glycolipids or phospholipids characteristic of gram-positive microorganisms.

The increases observed in the C16:1 content of marine sediment isolate 3SE8 with increased culture age were contrary to the findings reported in the literature for nonmarine microorganisms (43). Kates (31) and Marr and Ingraham (41) noted a decrease in the C16:1 content of $E$. coli with increased culture age, but the decrease was paralleled with an increase in the cyclic $\mathrm{C} 17$ concentration. A similar observation was cited for Lactobacillus, where a conversion of C18:1 to cyclic C19 (53) was noted. Also, $P$. aeruginosa showed a conversion of both $\mathrm{C} 16: 1$ and $\mathrm{C} 18: 1$ to cyclic $\mathrm{C} 17$ and C19 (23). No cyclic fatty acids were found to occur at any point in the growth of strain 3SE8, thus explaining the lack of conversion of the unsaturated species to the cyclic acids. The increased $\mathrm{C} 16: 1$ content may be correlated with the large increases in phosphatidylethanolamine observed for this isolate with increased culture age (44). The increase in the C16:1 component did not appear to be characteristic of the marine isolates, since isolate $3 \mathrm{SE} 7$ showed only a slight increase and 3S2 demonstrated a slight decrease. Whether the age effect on $\mathrm{C} 16: 1$ content was due to growth temperature or to medium used or was a feature of the organisms themselves is not known.

Lowering the growth temperature of Vibrio marinus strain PS-207 from 25 to $15 \mathrm{C}$ appeared to have an effect on fatty-acid composition similar to that reported for many nonmarine bacteria. No qualitative differences were found and no chain-length reduction was evident, with the effect of lowered temperature reflected primarily in an increase in C16:1. A mechanism as yet unelucidated may account for the selective increase in the unsaturated components, as shown by Okuyama (42).

It is interesting to compare the fatty-acid 
composition of $V$. marinus strain PS-207, grown at $15 \mathrm{C}$, with that of the obligately psychrophilic strain $V$. marinus MP-1 reported by Oró et al. (45). The fatty-acid composition of strain MP-1 was examined after harvesting the cells from the late logarithmic phase of growth. The major acids found were $\mathrm{C} 16: 1$ (31.1\%), C18:1 (22.8\%), C16 (19.6\%), and C14 $(14.4 \%)$, with an unsaturated-to-saturated $\mathrm{C} 16+\mathrm{C} 18$ ratio of 2.5 . This is quite different from that of strain PS-207, where C16:1 amounted to $57.5 \%$ and $\mathrm{C} 18: 1$ to only $9.3 \%$. When, on the other hand, the pattern found for strain PS-207 grown at $25 \mathrm{C}$ is compared with strain MP-1 grown at $15 \mathrm{C}$, the percentages of the major acids are similar, with C16:1 representing only $39.2 \%$ and $\mathrm{C} 18: 1$ amounting to $15.4 \%$, with an unsaturated-to-saturated $\mathrm{C} 16+\mathrm{C} 18$ ratio of 2.6 . It is clear that comparisons of fatty-acid composition among bacterial strains should be done by using extracts of cells grown at the temperature optimum for each of the strains tested. The optimal growth temperature is $25 \mathrm{C}$ for strain PS-207 and $15 \mathrm{C}$ for MP-1. Attempts to compare extracts of strains grown at $15 \mathrm{C}$ may well lead to erroneous conclusions. Growth of both strains at their temperature optima revealed similar fatty-acid profiles.

The effect of lowered salt concentration in the growth medium on the fatty acids of marine bacteria may be attributed to a weakening of the cell membrane, i.e., lack of screening of the electro-negative charges of the mucopeptide layer by the divalent salt cations (40). Similar findings were reported by Brown (11), who studied the effects of salt concentration on the cell envelope of a marine pseudomonad and found that cells grown in salt concentrations of 0.98 to $0.25 \mathrm{M}$ (equivalent to complete and one-half-strength salts media of this study), were "normal," whereas those grown in media containing less than $0.18 \mathrm{M}$ salts (the onequarter- and one-eighth-strength salts media of this study contained 0.11 and $0.055 \mathrm{M}$ salts, respectively) were short and somewhat rounded and gave reduced cell yields. The requirement for multivalent cations has been well documented for marine bacteria $(40,41)$. The possibility that marine microorganisms may not tolerate salt concentrations significantly lower than that of the open ocean (as, for example, in the estuary) is an interesting factor to be considered (S. O. Stanley and R. Y. Morita, Bacteriol. Proc., p. 45, 1967).

Cells grown in complete and one-halfstrength salts media were harvested after $7 \mathrm{~h}$ of growth, and those from one-quarter-strength salts medium were harvested after $22.5 \mathrm{~h}$. Changes in $\mathrm{C} 16$ and $\mathrm{C} 16: 1$ components that were noted may be due to increased age of the culture. O'Leary (43) noted that, in general, the percentage of saturated fatty acids increased with the age of the cultures. Results given in Table 3, however, showed little change in the percentage of either $\mathrm{C} 16$ or $\mathrm{C} 16: 1$ over a comparable growth period. It must, therefore, be concluded that salt concentration effected the differences observed in C16 and C16:1 fatty-acid content.

In conclusion, the fatty-acid profiles of the marine bacteria examined in this study were found to be similar to those of non-marine species. Some of the fatty acids of these microorganisms were noted and considered to be significant. Of the variety of fatty acids found to occur among the strains, C16:1 was dominant. In 14 of 22 strains, C16:1 was the predominant fatty acid, and in the other strains studied it was the second predominant species in all but the strain of Agrobacterium stellulatum. In our investigation of the effect of culture age on fatty-acid profiles, C16:1 was the only acid found to change significantly with increased time of growth. The same effect was observed for fatty acids of $V$. marinus strain PS-207, with C16:1 increasing significantly when the growth temperature was lowered from 25 to $15 \mathrm{C}$. Lowering the salt concentration caused the C16:1 content of bacterial isolate $3 \mathrm{SE} 8$ to be markedly reduced, with a compensatory increase noted in $\mathrm{C} 16$. The presence of C18:2 was found to be significant, since it was detected in extracts of 15 of the 20 marine and estuarine strains studied.

Growth temperature was found to be important in interpreting fatty-acid profiles of bacteria. Evidence obtained from this study suggests clearly that comparisons can be made only when organisms are grown at their temperature optima. The Vibrio strains examined were easily differentiated from the strains of other genera studied. The taxonomic position of Arthrobacter marinus must be reevaluated, and Photobacterium fischeri should be reassigned to the genus Vibrio, where it was placed by Lehmann and Neumann in 1896 (37).

Marine sediment isolates were not uniform in their fatty-acid profiles, although most of the isolates could be identified as belonging to the genus Vibrio on the basis of fatty-acid composition. Sediment isolate 3SE5 demonstrated a rather unique pattern wherein branched acids comprised the major class of fatty acids. 


\section{ACKNOWLEDGMENTS}

The generous assistance of Lily Wan in preparing the figures is gratefully acknowledged.

This work was supported by grant GB-35261 X from the National Science Foundation, Sea Grant Project GH-91, and contract no. N00014-69-A0220-0006 between the Office of Naval Research, Department of the Navy, and Georgetown University.

\section{REPRINT REQUESTS}

Address requests for reprints to: Dr. J. D. Oliver, Department of Biochemistry, University of Ottawa, Ontario, Canada K1N6N5.

\section{LITERATURE CITED}

1. Ackman, R. G. 1963. Structural correlation of unsaturated fatty acid esters through graphical comparison of gas-liquid chromatographic retention times on a polyester substrate. J. Amer. Oil Chem. Soc. 40:558-564.

2. Ackman, R. G. 1969. Gas-liquid chromatography of fatty acids and esters, p. 329-381. In J. M. Lowenstein (ed.), Methods in enzymology, vol. 14. Academic Press Inc., New York.

3. Albro, P. W., and J. C. Dittmer. 1970. Bacterial hydrocarbons: occurrence, structure and metabolism. Lipids 5:320-325.

4. Allison, M. J., M. P. Bryant, I. Katz, and M. Keeney. 1962. Metabolic function of branchedchain volatile fatty acids, growth factors for ruminococci. II. Biosynthesis of higher branchedchain fatty acids and aldehydes. J. Bacteriol. 83: 1084-1093.

5. Auran, T. B., and E. L. Schmidt. 1972. Similarities between Hyphomicrobium and Nitrobacter with respect to fatty acids. J. Bacteriol. 109:450-451.

6. Baumann, L., P. Baumann, M. Mandel, and R. Allen. 1972. Taxonomy of aerobic marine Eubacteria. J. Bacteriol. 110:402-429.

7. Blumer, M., T. Chase, and S. W. Watson. 1969. Fatty acids in the lipids of marine and terrestrial nitrifying bacteria. J. Bacteriol. 99:366-370.

8. Brian, B. L., and E. W. Gardner. 1968. Cyclopropane fatty acids of rugose Vibrio cholerae. J. Bacteriol. 96:2181-2182.

9. Brian, B. L., and E. W. Gardner. 1968. A simple procedure for detecting the presence of cyclopropane fatty acids in bacterial lipids. Appl. Microbiol. 16:549-552.

10. Brockerhoff, H. 1965. Stereospecific analysis of triglycerides: an analysis of human depot fat. Arch. Biochem. Biophys. 110:586-592.

11. Brown, A. D. 1961. Effects of salt concentration during growth on properties of the cell envelope of a marine pseudomonad. Biochem. Biophys. Acta 49:585-588.

12. Chalk, K. J. I., and E. Kodicek. 1961. The incorporation of $\left[\mathrm{Me}^{-14} \mathrm{C}\right]$ methionine into lacto- bacillic acid. Biochim. Biophys. Acta 50:579-581.

13. Cho, K. Y., and M. R. J. Salton. 1966. Fatty acid composition of bacterial membrane and wall lipids. Biochim. Biophys. Acta 116:73-79.

14. Christie, W. W. 1970. Cyclopropane and cyclopropene fatty acids, p. 1-49. In F. D. Gunstone (ed.), Topics in lipid chemistry, vol. 1. Logos Press Ltd., London.

15. Citarella, R. V., and R. R. Colwell. 1970. Polyphasic taxonomy of the genus Vibrio: polynucleotide sequence relationships among selected Vibrio species. J. Bacteriol. 104:434-442.

16. Colwell, R. R. 1970. Polyphasic taxonomy of the genus Vibrio: numerical taxonomy of Vibrio cholerae, Vibrio parahaemolyticus, and related Vibrio species. J. Bacteriol. 104:410-433.

17. Colwell, R. R., V. I. Adeyemo, and H. H. Kirtland. 1968. Esterases and DNA base composition analysis of Vibrio cholerae and related vibrios. J. Appl. Bacteriol. 31:323-335.

18. Cronan, J. E. 1968. Phospholipid alterations during growth of Escherichia coli. J. Bacteriol. 95:2054-2061.

19. DeVoe, I. W., and E. L. Oginsky. 1969. Cation interactions and biochemical composition of the cell envelope of a marine bacterium. J. Bacteriol. 98: 1368-1377.

20. Eberhard, A., and G. Rouser. 1971. Quantitative analysis of the phospholipids of some marine bioluminescent bacteria. Lipids 6:410-414.

21. Goldfine, H., and M. E. Ellis. 1964. $N$-methyl groups in bacterial lipids. J. Bacteriol. 87:8-15.

22. Gray, G. M. 1967. Gas chromatography of the long-chain aldehydes, p. 401-427. In G. V. Marinetti (ed.), Lipid chromatographic analysis, vol. 1. Marcel Dekker, Inc., New York.

23. Hancock, I. C., and P. M. Meadow. 1969. The extractable lipids of Pseudomonas aeruginosa. Biochim. Biophys. Acta 187:366-379.

24. Hastings, J. W. 1966. The chemistry of bioluminescence, p. 113-153. In D. R. Sanadi (ed.), Current topics in bioenergetics, vol. 1. Academic Press Inc., New York.

25. Hildebrand, J. G., and J. H. Law. 1964. Fatty acid distribution in bacterial phospholipids. The specificity of the cyclopropane synthetase reaction. Biochemistry 3:1304-1308.

26. Hofmann, K., and F. Tausig. 1955. On the identity of phytomonic and lactobacillic acids. A reinvestigation of the fatty acid spectrum of Agrobacterium (Phytomonas) tumefaciens. J. Biol. Chem. 213:425-432.

27. Hunter, G. D., and A. T. James. 1963. Lipoaminoacids from Bacillus megaterium. Nature (London) 198: 789

28. Huston, C. K., and P. W. Albro. 1964. Lipids of Sarcina lutea. I. Fatty acid composition of the extractable lipids. J. Bacteriol. 88:425-432.

29. Jamieson, G. R. 1970. Structure determination of fatty esters by gas liquid chromatography, $p$. 107-155. In F. D. Gunstone (ed.), Topics in lipid chemistry, vol. 1. Logos Press Ltd., London.

30. Kaneshiro, T., and A. G. Marr. 1961. Cis-9, 10-methylene hexadecanoic acid from the phos- 
pholipids of Escherichia coli. J. Biol, Chem. 236:2615-2619.

31. Kates, M. 1964. Bacterial lipids. Advan. Lipid Res. 2:17-90.

32. Kates, M., and P.-O. Hagen. 1964. Influence of temperature on fatty acid composition of psychrophilic and mesophilic Serratia species. Can. J. Biochem. 42:481-488.

33. Knivett, V., and J. Cullen. 1965. Some factors affecting cyclopropane acid formation in Escherichia coli. Biochem. J. 96:771-776.

34. Kojima, R. 1971. Fatty acid composition of bacteria and their application to bacterial classification. Jap. J. Bacteriol. 26:311-318.

35. Kostiw, L. L., C. W. Boylen, and B. J. Tyson. 1972. Lipid composition of growing and starving cells of Arthrobacter crystallopoietes. J. Bacteriol. 111:103-111.

36. Law, J. H., H. Zalkin, and T. Kaneshiro. 1963. Transmethylation reactions in bacterial lipids. Biochim. Biophys. Acta 70:143-151.

37. Lehmann, K. B., and R. Neumann. 1896. Atlas und Grundriss der Bakteriologie und Lehrbuch der speciellen bacteriologischen Diagnostik. Teil II, p. $1-448$.

38. Lennarz, W. J. 1970. Bacterial lipids, p. 155-184. In S. J. Wakil (ed.), Lipid metabolism. Academic Press Inc., New York.

39. MacLeod, R. A. 1965. The question of the existence of specific marine bacteria. Bacteriol. Rev. 29:9-22.

40. MacLeod, R. A. 1968. On the role of inorganic ions in the physiology of marine bacteria, $p$. 95-126. In M. R. Droop and E. J. F. Wood (ed.), Advances in microbiology of the sea, vol. 1 . Academic Press Inc., New York.

41. Marr, A. G., and J. L. Ingraham. 1962. Effect of temperature on the composition of fatty acids in Escherichia coli. J. Bacteriol. 84:1260-1267.

42. Okuyama, H. 1969. Phospholipid metabolism in Escherichia coli after a shift in temperature. Biochim. Biophys. Acta 176:125-134.

43. O'Leary, W. M. 1967. The chemistry and metabolism of microbial lipids. The World Publishing Co., Cleveland.

44. Oliver, J. D., and R. R. Colwell. 1973. Extractable lipids of gram-negative marine bacteria: phospholipid composition. J. Bacteriol. 114:897-908.

45. Oró, J., T. G. Tornabene, D. W. Nooner, and E. Gelpi. 1967. Aliphatic hydrocarbons and fatty acids of some marine and freshwater microorganisms. J. Bacteriol. 93:1811-1818.

46. Ray, P. H., D. C. White, and T. D. Brock. 1971. Effect of temperature on the fatty acid composition of Thermus aquaticus. J. Bacteriol. 106:25-30.

47. Romero, E. M., and R. R. Brenner. 1966. Fatty acids synthesized from hexadecane by Pseudomonas aeruginosa. J. Bacteriol. 91:183-188.

48. Shaw, N., and D. Stead. 1971. Lipid composition of some species of Arthrobacter. J. Bacteriol. 107:130-133.

49. Shaw, R. 1966. The polyunsaturated fatty acids of microorganisms. Advan. Lipid Res. 4:107-174.

50. Sinensky, M. 1971. Temperature control of phospholipid biosynthesis in Escherichia coli. J. Bacteriol. 106:449-455.

51. Tornabene, T. G., E. O. Bennett, and J. Oró. 1967. Fatty acid and aliphatic hydrocarbon composition of Sarcina lutea grown in three different media. J. Bacteriol. 94:344-348.

52. Tornabene, T. G., E. Gelpi, and J. Oró. 1967. Identification of fatty acids and aliphatic hydrocarbons in Sarcina lutea by gas chromatography and combined gas chromatography-mass spectrometry. J. Bacteriol. 94:333-343.

53. Veerkamp, J. H. 1971. Fatty acid composition of Bifidobacterium and Lactobacillus strains. J. Bacteriol. 108:861-867.

54. White, D. C., and R. H. Cox. 1967. Identification and localization of the fatty acids in Haemophilus parainfluenzae. J. Bacteriol. 93: 1079-1088.

55. Yano, I., Y. Furukawa, and M. Kusunose. 1971. Fatty-acid composition of Arthrobacter simplex grown on hydrocarbons. Occurrence of $\alpha$ hydroxy-fatty acids. Eur. J. Biochem. 23:220228.

56. ZoBell, C. E., and H. C. Upham. 1944. A list of marine bacteria including descriptions of sixty new species. Bull. Scripps Inst. Oceanogr. Univ. Calif. 5:239-292. 